\title{
Effective interventions to improve the health literacy of cancer patients
}

\author{
Loreto Fernández-González ${ }^{1}$ and Paulina Bravo-Valenzuela ${ }^{2,3}$ \\ ${ }^{1}$ Dalla Lana School of Public Health, University of Toronto, 155 College Street, Toronto, ON M5T 3M7, Canada \\ ${ }^{2}$ Nursing School, Pontificia Universidad Catolica de Chile, Santiago 7820436, Chile \\ ${ }^{3}$ School of Social Sciences, Cardiff University, Cardiff CF10 3NN, UK
}

\section{Abstract}

Health literacy $(\mathrm{HL})$ refers to the cognitive and social abilities that are determinants in the motivation and capacity of the individual to access, understand and use information for the care of one's own health. In oncology, increased survival, navigation of the healthcare system, the many different forms of treatment and the management of adverse effects/ outcomes make $\mathrm{HL}$ a critical factor in patient care. The objective of this study is to identify the structure, content and effectiveness of interventions to improve $\mathrm{HL}$ in cancer patients.

Materials and methods: A literature review was performed using the '(health literacy OR Cancer Literacy) AND Cancer AND Intervention' strategy on seven multidisciplinary databases. Studies that intervened in subjects diagnosed with cancer and treating HL explicitly as a variable to be measured were included.

Results: One thousand two hundred and thirty-six abstracts were retrieved. Eight studies met the inclusion criteria. Research focused on patients diagnosed with breast cancer or prostate cancer. Interventions used multimedia resources and face-to-face interactions. No study defined HL. HL was usually a secondary outcome. There is high variability in the design of studies and interventions and in the instruments used to measure HL. The effectiveness of the interventions varied between studies, with improvements that were diminished over time or insufficient in participants with initial low literacy.

Conclusion: The evidence to date in interventions oriented to study $\mathrm{HL}$ in patients with cancer is focused on other constructs, leaving $\mathrm{HL}$ as a phenomenon difficult to define both conceptually and clinically. Variability in designs and measurements makes comparison between interventions difficult. Defining and operationalizing $\mathrm{HL}$ is critical to design and measure effective interventions, which must be adapted to patients' needs.

Keywords: health literacy (HL), health education, cancer, result evaluation (health care), literature review

\section{Introduction}

Health literacy $(\mathrm{HL})$, also known as functional $\mathrm{HL}$, refers to the cognitive and social abilities that have a determining role in the motivation and capacity of the individual to

Correspondence to: Paulina Bravo-Valenzuela Email: pbbravo@uc.cl

ecancer 2019, 13:966

https://doi.org/10.3332/ecancer.2019.966

Published: $10 / 10 / 2019$

Received: 20/02/2019

Copyright: (c) the authors; licensee ecancermedicalscience. This is an Open Access article distributed under the terms of the Creative Commons Attribution License (http:// creativecommons.org/licenses/by/3.0), which permits unrestricted use, distribution, and reproduction in any medium, provided the original work is properly cited. 
access, understand and use information in order to promote their own health [1]. The concept of HL was introduced in the mid-seventies and has been gaining relevancy to the extent that evidence shows that it is the strongest predictor of a person's health status, along with other social determinants such as age, income, work status, educational level and race/ethnicity [2]. For example, those subjects and groups with low levels of $\mathrm{HL}$ are at risk of having worse health than those who possess better HL, which leads to the reproduction of health inequities [1]. According to Edwards et al [3], the conceptual development of $\mathrm{HL}$ has been evolving from a notion fundamentally centred on the cognitive ability of the patient to adequately process information to models based on action orientation and successful interactions with healthcare providers and participation in the decision-making process. There are currently multiple definitions and conceptual models to understand HL. The model presented by the World Health Organisation (WHO) [1] based on the European Health Literacy Consortium includes 12 subdivisions under the categories of health promotion, illness prevention and healthcare. From this point of view, $\mathrm{HL}$ integrates and interacts with concepts such as empowerment and sustainability. Developing a HL model for chronic illnesses, Edwards et al [3] distinguished eight elements: health knowledge, self-care skills, active search and use of information, active communication with the healthcare team, search of treatment options, decision-making, influence of others in $\mathrm{HL}$ and expected results in $\mathrm{HL}$.

Defining $\mathrm{HL}$ is key to operationalize and measure the construct in terms of low or high $\mathrm{HL}$, and for designing interventions aiming to improve it. This is not only critical from a scientific and methodological point of view but also from the point of view of public policy for implementing evidence-based strategies to promote $\mathrm{HL}[4,5]$.

This fact is particularly important from a public health viewpoint, given the sustained increase in chronic illnesses that require constant effort in self-management by patients and their caregivers [3]. On the other hand, the complexity of health systems and the development of new communication technologies have allowed immediate and continued access to health information, entailing a challenge to individuals, governments and international organisations [2], which can impact people's level of HL. In addition, research has demonstrated that the subjects with low HL have limited participation in healthcare appointments and in decision-making, make more calls to emergency services, have a higher number of hospitalisations and present poor self-care in general [3], thereby directly impacting healthcare costs.

$\mathrm{HL}$ is an area of health promotion in terms of the adoption of healthy habits and early detection behaviours, particularly necessary in patients with chronic illnesses, which have increased globally both in incidence and survival [3,6]. Daily management of chronic illness requires the use of functional, cognitive and social resources. Optimal care for these patients involves frequent contact with the healthcare system and active management of the health condition. People with low HL engage less effectively in activities related to their own health management, resulting in increased disease burden and overall worse health outcomes [6, 7]. Therefore, an adequate and comprehensive understanding of patients' HL is necessary if successful interventions and services are intended to be implemented. In the context of cancer care, the increase in survival, the navigation in the healthcare system, the multiplicity of treatment options and the management of adverse effects/sequelae of short, medium and long terms make $\mathrm{HL}$ a critical factor in patient care [8].

Regarding conceptual models on HL in cancer and its role in health outcomes, the work of Echeverri et al [9] stands out; they define it as the ability of the individual to search, understand, evaluate and use basic information to take appropriate decisions regarding prevention, diagnosis and treatment of cancer. Due to the fact that it is not directly observable and has a multidimensional nature [9], the development of interventions designed to improve $\mathrm{HL}$ in cancer poses important methodological and technical challenges.

Knowing the type of interventions-both clinical and community-based-and their effectiveness described in the literature constitutes a logical and decisive step in order to implement and tailor them to local contexts. Hence, the present article is a structured literature review conducted with the objective of knowing and describing the effectiveness of interventions aimed at improving the HL of patients diagnosed with cancer.

\section{Materials and methods}

A structured review of available evidence was conducted following international recommendations for the assurance of methodological rigour $[10,11]$. Due to the exploratory nature of the review, a narrative review was conducted rather than a systematic one, focused on qualitatively describing the studies and their strengths and weaknesses, following PRISMA guidelines in the screening and selection of the articles to ensure the inclusion of relevant studies. For this reason, we used the term 'intervention', understanding this as the development of actions regarding the condition to modify the cancer $\mathrm{HL}$ of the participants, whether by the increase in knowledge, self-care strategies, 
decision-making to the condition, use of health services or similar. In the same way, no a priori definitions or specific conceptual frameworks of $\mathrm{HL}$ were used to restrictively select the studies.

\section{Search strategy}

The inclusion criteria for the articles were: 1) studies published in scientific journals in English or Spanish with no start date limit until 2017; 2) studies reporting interventions that explicitly consider $\mathrm{HL}$ as an outcome or variable and 3 ) the participants of the study are cancer patients with any type of cancer and stage. Studies centred on the development of instruments for measuring HL, or conducted in healthy or nononcological population were excluded.

With the goal of identifying pertinent articles, the following search algorithm was constructed with the help of an expert librarian: '(Health Literacy OR Cancer Literacy) AND Cancer AND Intervention' in 'All categories' (or its nearest equivalent according to the database used), in English and Spanish. The following databases were selected, privileging their multidisciplinary nature in health: Pubmed, Web of Science, CINAHL, Psyclnfo, Scopus, Epistemonikos and Scielo. The literature search in databases was conducted during the month of May 2017.

\section{Studies selection and data extraction}

Types of texts were not filtered a priori to cover as many documents as possible. Articles of qualitative, quantitative or mixed methodology were included. The systematic or narrative reviews were included as a source of possible articles of interest in their references. Grey literature was not considered. Once duplicates were eliminated, a researcher (LFG) reviewed the titles of all the articles, verifying compliance with the inclusion criteria. An independent screening was conducted on $10 \%$ of the titles between both authors (LFG and PBV) in order to unify selection criteria. The following phase included the reading of the abstracts in order to evaluate the pertinence of the study's inclusion in accordance with the objective of this review. A narrative analysis was conducted on the information obtained, categorising the characteristics of the interventions and the report of their effectiveness [12]. Data extraction was conducted using a matrix including general information (year and country), type of study, type of cancer and sample data, definition of HL used, characteristics of the intervention, instruments used for measuring $\mathrm{HL}$, the effects of the intervention and results obtained.

1,236 results were retrieved. Duplicates were eliminated, resulting in 616 articles that were reviewed in title and abstract. From this phase, articles for full reading were selected, of which one article was excluded due to the unavailability of the original article. In addition, in this phase of exploratory screening, one additional article from a systematic review that met the inclusion criteria was included. Thirty-one articles were selected for full-text reading for further evaluation. Of these, 23 articles were discarded, either for not reporting HL in their results $(N=5)$ for corresponding to a literature review $(N=7)$, for being articles whose studies do not include subjects with cancer $(N=6)$ or do not include an intervention $(N=2)$, for corresponding to a research protocol $(N=1)$ and finally, for reporting the development of a scale and not a intervention $(N=1)$. Finally, a total of nine articles corresponding to eight studies (one study published preliminary and final results, both were included) met the inclusion criteria were included in the review. The selection process of the articles is shown in Figure 1.

\section{Results}

Table 1 summarises the characteristics of the articles that met the inclusion criteria.

\section{Characteristics of the studies}

All studies included according to the exposed criteria were conducted in the United States. Regarding the type of cancer diagnosis, all studies worked with adult patients with only one type of cancer, with 50\% (4/8) of the studies conducted in women patients with breast cancer [14-18] and 50\% (4/8) in patients with prostate cancer [19-22]. Only one study [17] included both healthy subjects and diagnosed patients. Only one study included solely patients with non-metastatic cancer [14, 15], while $3 / 8$ reported including subjects with early and advanced stages of cancer $[18,19,22]$; in other studies, these data were not reported. The types of studies selected utilised designs with qualitative 
$(N=1)[16]$ and quantitative methods such as randomised clinical trials $(N=3)[12,13,15,19]$ and prospective cohort studies $(N=4)[18,20$, 22]. The sample size of the studies has an average of 71 patients, varying between 12 [16] and 130 patients [18], with an emphasis on the participation of minorities in the American context (African-American and Latino/as). The outcomes of the studies include increased knowledge regarding one's own health [18, 22], decision-making regarding oncological treatments $[14,15,19]$, management of specific tumour site terminology [20], improving adherence to medical treatments [17, 18], adoption of self-care practices [15, 19] and promoting access to participation in clinical trials [16]. The tools used in the studies show great variability, with the questionnaire Rapid Estimate of Adult Literacy in Medicine (REALM) being the most used, in 37.5\% of the studies (3/8) [19-21]. Regarding HL conceptualization, none of the studies report a definition of the construct.
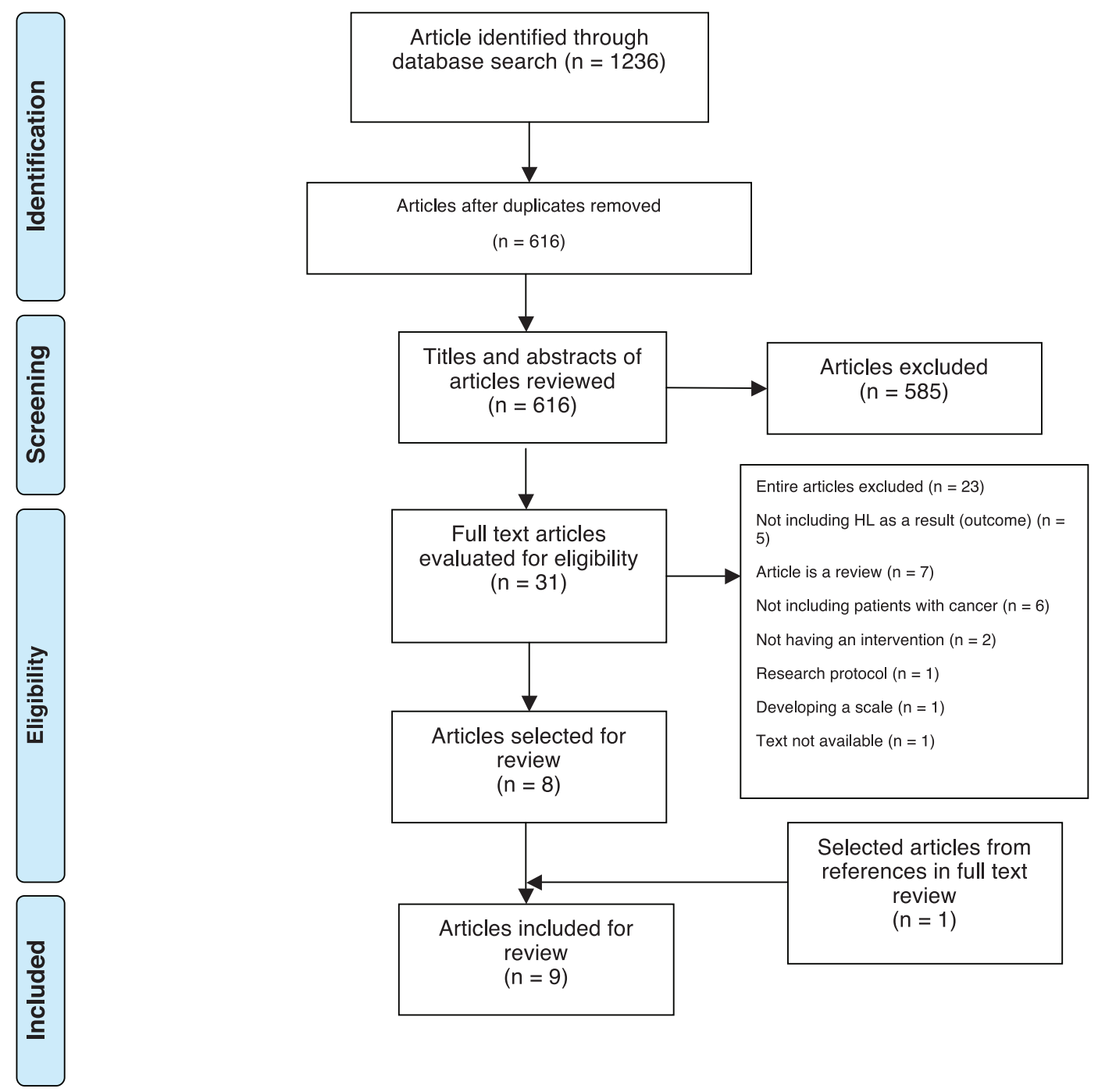

Figure 1. Flowchart of the article identification process. 
Table 1. Articles included in the review.

\begin{tabular}{|c|c|c|c|c|c|c|c|}
\hline Article & Type of study & $\begin{array}{l}\text { Country } \\
\text { of study }\end{array}$ & Sample & $\begin{array}{l}\text { Result or vari- } \\
\text { able of interest } \\
\text { (outcomes) }\end{array}$ & $\begin{array}{l}\text { HL measurement } \\
\text { and other } \\
\text { instruments used }\end{array}$ & $\begin{array}{l}\text { Intervention } \\
\text { characteristics }\end{array}$ & Results obtained \\
\hline $\begin{array}{l}\text { Jibaja-Weiss } \\
\text { et al }[14]\end{array}$ & $\begin{array}{l}\text { Randomised } \\
\text { controlled } \\
\text { trial. Only } \\
\text { intervened } \\
\text { group is } \\
\text { reported. }\end{array}$ & US & $\begin{array}{l}\text { Fifty-one } \\
\text { women with } \\
\text { breast cancer } \\
\text { recently } \\
\text { diagnosed. } \\
\text { Majority of } \\
\text { Latin or } \\
\text { African } \\
\text { American } \\
\text { origin. }\end{array}$ & $\begin{array}{l}\text { Decision-mak- } \\
\text { ing regarding } \\
\text { breast surgery. }\end{array}$ & $\begin{array}{l}\text { 1) Decisional } \\
\text { conflict scale } \\
\text { (low literacy } \\
\text { version). }\end{array}$ & $\begin{array}{l}\text { (CPtDA): computerised pa- } \\
\text { tient decision aid. Edutain- } \\
\text { ment (a patchwork of life: a } \\
\text { woman's story for making } \\
\text { breast cancer treatment } \\
\text { decisions). Video with soap } \\
\text { opera narrative structure } \\
\text { and interactive learning } \\
\text { modules. Patient watches } \\
\text { the video after medical } \\
\text { consultation and receives } \\
\text { personalised brochure. }\end{array}$ & $\begin{array}{l}\text { There is a significant } \\
\text { decrease in uncertainty and } \\
\text { personal values after the } \\
\text { intervention. }\end{array}$ \\
\hline $\begin{array}{l}\text { Jibaja-Weiss } \\
\text { et al [15] }\end{array}$ & $\begin{array}{l}\text { Randomised } \\
\text { controlled } \\
\text { trial }\end{array}$ & US & $\begin{array}{l}\text { One hun- } \\
\text { dred women } \\
\text { recently } \\
\text { diagnosed } \\
\text { with breast } \\
\text { cancer. Major- } \\
\text { ity of Latin or } \\
\text { African } \\
\text { American } \\
\text { origin. }\end{array}$ & $\begin{array}{l}\text { Decision-mak- } \\
\text { ing regarding } \\
\text { breast surgery. }\end{array}$ & $\begin{array}{l}\text { 1) Decisional } \\
\text { conflict scale } \\
\text { (low literacy } \\
\text { version). } \\
\text { 2) Breast cancer } \\
\text { knowledge } \\
\text { questionnaire. } \\
\text { 3) Satisfaction } \\
\text { with decision } \\
\text { scale. } \\
\text { 4) Satisfaction } \\
\text { with the } \\
\text { decision- } \\
\text { making } \\
\text { process } \\
\text { questionnaire. } \\
\text { 5) Satisfac- } \\
\text { tion with } \\
\text { programme } \\
\text { questionnaire. }\end{array}$ & $\begin{array}{l}\text { CPtDA. Edutainment } \\
\text { (a patchwork of life: a } \\
\text { woman's story for making } \\
\text { breast cancer treatment } \\
\text { decisions). Video with soap } \\
\text { opera narrative structure } \\
\text { and interactive } \\
\text { learning modules. } \\
\text { Patient watches the video } \\
\text { after receiving medical } \\
\text { consultation and person- } \\
\text { alised brochure. }\end{array}$ & $\begin{array}{l}\text { Unexpected result: inter- } \\
\text { vened group chooses more } \\
\text { to have modified radical } \\
\text { mastectomy. There is a } \\
\text { significant difference } \\
\text { between groups in } \\
\text { knowledge about the } \\
\text { disease, but they are equal } \\
\text { after one year. There is no } \\
\text { significant difference } \\
\text { between groups in satisfac- } \\
\text { tion with decision. The } \\
\text { decision conflict decreases } \\
\text { over time, with both groups } \\
\text { equalising each year. }\end{array}$ \\
\hline $\begin{array}{l}\text { Kim et al } \\
{[19]}\end{array}$ & $\begin{array}{l}\text { Prospective } \\
\text { cohort }\end{array}$ & US & $\begin{array}{l}\text { Thirty } \\
\text { patients } \\
\text { recently } \\
\text { diagnosed } \\
\text { with prostate } \\
\text { cancer. Half } \\
\text { African } \\
\text { Americans. }\end{array}$ & $\begin{array}{l}\text { Shared } \\
\text { decision-mak- } \\
\text { ing regarding } \\
\text { treatments } \\
\text { for prostate } \\
\text { cancer. }\end{array}$ & $\begin{array}{l}\text { 1) Prostate } \\
\text { cancer } \\
\text { knowledge } \\
\text { questionnaire } \\
\text { (PCKQ). } \\
\text { 2) Rapid estimate } \\
\text { of adult } \\
\text { literacy in } \\
\text { medicine } \\
\text { (REALM). }\end{array}$ & $\begin{array}{l}\text { CD-ROM with shared } \\
\text { decision-making pro- } \\
\text { gramme. Includes videos, } \\
\text { images and personalised } \\
\text { information about the dis- } \\
\text { ease. Follow-up to check } \\
\text { treatment choice and treat- } \\
\text { ment performed. }\end{array}$ & $\begin{array}{l}\text { More than } 75 \% \text { of } \\
\text { the patients rated the } \\
\text { programme as very } \\
\text { satisfactory. Patients' } \\
\text { HL correlates with their } \\
\text { level of knowledge about } \\
\text { prostate cancer. Two-thirds } \\
\text { of the patients chose a } \\
\text { treatment option. How- } \\
\text { ever, one-third received } \\
\text { a different treatment } \\
\text { than preferred after the } \\
\text { intervention. }\end{array}$ \\
\hline
\end{tabular}


Table 1. (Continued) Articles included in the review.

\begin{tabular}{|c|c|c|c|c|c|c|c|}
\hline $\begin{array}{l}\text { Nickell et al } \\
\text { [16] }\end{array}$ & $\begin{array}{l}\text { Participatory } \\
\text { research and } \\
\text { intervention } \\
\text { piloting }\end{array}$ & US & $\begin{array}{l}\text { Twelve breast } \\
\text { cancer survi- } \\
\text { vors of diverse } \\
\text { ethnicity and } \\
\text { four clinical } \\
\text { trial naviga- } \\
\text { tors. }\end{array}$ & $\begin{array}{l}\text { Promote } \\
\text { access to } \\
\text { participation in } \\
\text { clinical trials. }\end{array}$ & $\begin{array}{l}\text { Not measured } \\
\text { directly. }\end{array}$ & $\begin{array}{l}\text { HREl: health research } \\
\text { engagement intervention. } \\
\text { Intervention given by } \\
\text { personal navigator with } \\
\text { five components: } \\
\text { 1) explanation about health } \\
\text { research and its value; } \\
\text { 2) a card with health } \\
\text { research resources, } \\
\text { which contains a list of } \\
\text { services with available } \\
\text { information; } \\
\text { 3) brief questionnaire } \\
\text { about the medical } \\
\text { history to identify } \\
\text { appropriate studies; } \\
\text { 4) personalised list with } \\
\text { appropriate studies } \\
\text { 5) comments on the } \\
\text { studies. }\end{array}$ & $\begin{array}{l}\text { The total number of } \\
\text { women who responded } \\
\text { to the follow-up ( } n=11 \text { ) } \\
\text { showed acceptability of } \\
\text { the intervention and of the } \\
\text { patient navigator. }\end{array}$ \\
\hline $\begin{array}{l}\text { Rust et al } \\
\text { [17] }\end{array}$ & $\begin{array}{l}\text { Pilot ran- } \\
\text { domised } \\
\text { controlled } \\
\text { trial }\end{array}$ & US & $\begin{array}{l}\text { Forty-eight } \\
\text { African- } \\
\text { American } \\
\text { breast cancer } \\
\text { survivors. }\end{array}$ & $\begin{array}{l}\text { Improvement } \\
\text { of adherence } \\
\text { to medical } \\
\text { treatments. }\end{array}$ & $\begin{array}{l}\text { 1) Self-efficacy } \\
\text { for appropri- } \\
\text { ate medica- } \\
\text { tion use scale } \\
\text { (SEAMS). } \\
\text { 2) Adherence } \\
\text { to refills and } \\
\text { medications } \\
\text { scale (ARMS). } \\
\text { 3) Self-created } \\
\text { questions to } \\
\text { measure HL. }\end{array}$ & $\begin{array}{l}\text { MST: The medication } \\
\text { adherence skills training; } \\
\text { 2-hour group workshop } \\
\text { taught by pharmacists } \\
\text { and social workers. The } \\
\text { workshop content includes } \\
\text { information on the correct } \\
\text { use of medications, } \\
\text { communication skills and } \\
\text { overcoming barriers to } \\
\text { pharmacological adherence. }\end{array}$ & $\begin{array}{l}\text { There is a significant } \\
\text { correlation between } \mathrm{HL} \text {, } \\
\text { self-efficacy and adherence } \\
\text { to treatments. There are } \\
\text { no significant differences } \\
\text { between both groups after } \\
\text { the intervention. }\end{array}$ \\
\hline $\begin{array}{l}\text { Ulloa et al } \\
\text { [18] }\end{array}$ & $\begin{array}{l}\text { Prospective } \\
\text { cohort }\end{array}$ & US & $\begin{array}{l}\text { One hundred } \\
\text { and thirty } \\
\text { women with } \\
\text { breast } \\
\text { cancer. Most } \\
\text { Latin. }\end{array}$ & $\begin{array}{l}\text { 1) Increased } \\
\text { knowledge } \\
\text { about one's } \\
\text { own health. } \\
\text { 2) Improve- } \\
\text { ment of } \\
\text { adherence } \\
\text { to medical } \\
\text { treatments. } \\
\text { 3) Adoption of } \\
\text { self-care } \\
\text { practices. }\end{array}$ & $\begin{array}{l}\text { Single item } \\
\text { literacy screener. } \\
\text { Pre-post } \\
\text { assessment. } \\
\text { Satisfaction with } \\
\text { the intervention, } \\
\text { comprehen- } \\
\text { sibility of the } \\
\text { material and } \\
\text { communication } \\
\text { with the health- } \\
\text { care team was } \\
\text { measured. }\end{array}$ & $\begin{array}{l}\text { Patient receives a card that } \\
\text { contains information about } \\
\text { the stage of the tumour, } \\
\text { nodal status and treatments } \\
\text { received. It is completed by } \\
\text { the study coordinator, along } \\
\text { with the delivery of recom- } \\
\text { mendations for healthy } \\
\text { living and follow-up ( } 5 \text { min). } \\
\text { Then, the information is } \\
\text { reviewed individually with } \\
\text { the patient by a profession- } \\
\text { al navigator or community } \\
\text { health worker (10-15 min). }\end{array}$ & $\begin{array}{l}\text { Knowledge about the } \\
\text { disease (stage, treatments } \\
\text { received, nodal status, } \\
\text { follow-up, recommenda- } \\
\text { tions and healthy lifestyles) } \\
\text { increased significantly. The } \\
\text { card format for the wallet } \\
\text { had high acceptability } \\
\text { (93\%). }\end{array}$ \\
\hline
\end{tabular}


Table 1. (Continued) Articles included in the review.

\begin{tabular}{|c|c|c|c|c|c|c|c|}
\hline $\begin{array}{l}\text { Wang DS } \\
{[20]}\end{array}$ & $\begin{array}{l}\text { Prospective } \\
\text { cohort }\end{array}$ & US & $\begin{array}{l}\text { Fifty-six adult } \\
\text { men with } \\
10 \% \text { of men } \\
\text { diagnosed } \\
\text { with prostate } \\
\text { cancer. Most } \\
\text { African } \\
\text { Americans. }\end{array}$ & $\begin{array}{l}\text { Management } \\
\text { of specific } \\
\text { terminology of } \\
\text { the genitouri- } \\
\text { nary system } \\
\text { and prostate } \\
\text { cancer. }\end{array}$ & $\begin{array}{l}\text { 1) Kilbridge } \\
\text { questionnaire. } \\
\text { 2) Schwartz- } \\
\text { Woloshin } \\
\text { numbering } \\
\text { test. } \\
\text { 3) REALM. }\end{array}$ & $\begin{array}{l}\text { PCLA: prostate cancer } \\
\text { literacy application. } \\
\text { Audiovisual educational } \\
\text { tool (video). Content il- } \\
\text { lustrates medical terms } \\
\text { in a clinical context. } \\
\text { Each term is illustrated } \\
\text { in three-dimensional } \\
\text { animations, with some } \\
\text { explained in greater detail } \\
\text { in two dimensions. The } \\
\text { use of medical jargon was } \\
\text { avoided. The videos have } \\
\text { a duration of } 16 \text { min and } \\
\text { cover the urinary, sexual } \\
\text { and intestinal systems. } \\
\text { After each video, the } \\
\text { patient evaluates their } \\
\text { understanding of the } \\
\text { contents. }\end{array}$ & $\begin{array}{l}\text { There was a significant } \\
\text { increase in the } \\
\text { understanding of } \\
\text { medical terminology in } \\
13 \text { of the } 32 \text { terms, and } \\
\text { in the identification and } \\
\text { location of organs of the } \\
\text { genitourinary system. } \\
\text { Patients with low literacy } \\
\text { had a greater increase } \\
\text { in the understanding of } \\
\text { terminology related to } \\
\text { sexual functions than } \\
\text { subjects with high literacy; } \\
\text { however, they had no } \\
\text { significant differences } \\
\text { in the understanding of } \\
\text { urinary and intestinal } \\
\text { terms. }\end{array}$ \\
\hline $\begin{array}{l}\text { Wilson et al } \\
\text { [21] }\end{array}$ & $\begin{array}{l}\text { Randomised } \\
\text { three-arm } \\
\text { controlled } \\
\text { trial. }\end{array}$ & US & $\begin{array}{l}\text { Seventy } \\
\text { patients with } \\
\text { prostate } \\
\text { cancer with } \\
\text { indication of } \\
\text { radiotherapy. } \\
\text { Most African } \\
\text { Americans. }\end{array}$ & $\begin{array}{l}\text { Adoption of } \\
\text { self-care } \\
\text { practices. }\end{array}$ & $\begin{array}{l}\text { 1) REALM. } \\
\text { 2) Side-effect } \\
\text { interview (SEI). } \\
\text { 3) Mood's } \\
\text { self-care } \\
\text { management } \\
\text { techniques } \\
\text { checklist. }\end{array}$ & $\begin{array}{l}\text { Group 1: educational } \\
\text { intervention arm with } \\
\text { three videos and printed } \\
\text { material: Patients see } \\
\text { before the start of } \\
\text { treatment a first video } \\
\text { about introduction to } \\
\text { radiotherapy treatment. } \\
\text { Content includes the } \\
\text { planning and treatment } \\
\text { process, staff roles, opera- } \\
\text { tion of radiotherapy and } \\
\text { treatment machines, and } \\
\text { effects of radiotherapy } \\
\text { on lifestyle. The second } \\
\text { video is shown in the third } \\
\text { week of treatment and } \\
\text { deals with adverse effects } \\
\text { and self-care measures. } \\
\text { The third and final video } \\
\text { is shown at the end of the } \\
\text { treatment and addresses } \\
\text { emotional reactions and } \\
\text { ways of coping with physi- } \\
\text { cal and emotional effects } \\
\text { after treatment, as well as } \\
\text { information on resources in } \\
\text { the community. }\end{array}$ & $\begin{array}{l}\text { Men with low literacy } \\
\text { increased their care in the } \\
\text { intervened groups. Adverse } \\
\text { effects were similar in all } \\
\text { three groups. There was } \\
\text { an increase in the use of } \\
\text { self-care techniques over } \\
\text { time, but no significant } \\
\text { differences were found } \\
\text { between groups. The use } \\
\text { of self-care techniques } \\
\text { had significant differences } \\
\text { between patients with high } \\
\text { and low literacy. }\end{array}$ \\
\hline
\end{tabular}


Table 1. (Continued) Articles included in the review.

\begin{tabular}{|c|c|c|c|c|c|c|c|}
\hline & & & & & & $\begin{array}{l}\text { Group 2: educational } \\
\text { intervention arm and } \\
\text { agreement (contract) on } \\
\text { self-care behaviours. This } \\
\text { strategy is implemented } \\
\text { through a contract made } \\
\text { between the nurse of } \\
\text { the study and the patient } \\
\text { according to objectives } \\
\text { defined together in the } \\
\text { context of treatment. This } \\
\text { technique helps patients } \\
\text { identify self-care } \\
\text { behaviours regarding the } \\
\text { physical, emotional and } \\
\text { social adverse } \\
\text { effects of the treatment. A } \\
\text { care plan signed by both is } \\
\text { established. Rewards (basic } \\
\text { care products, etc.) are } \\
\text { delivered upon meeting } \\
\text { the objectives. Group 3: } \\
\text { usual care. }\end{array}$ & \\
\hline $\begin{array}{l}\text { Zavala et al } \\
\text { [22] }\end{array}$ & $\begin{array}{l}\text { Prospective } \\
\text { cohort }\end{array}$ & US & $\begin{array}{l}\text { One hundred } \\
\text { and fourteen } \\
\text { homeless men } \\
\text { in treatment } \\
\text { for prostate } \\
\text { cancer. Mostly } \\
\text { of Latin } \\
\text { heritage. }\end{array}$ & $\begin{array}{l}\text { Increased } \\
\text { knowledge } \\
\text { about one's } \\
\text { own health. }\end{array}$ & $\begin{array}{l}\text { Self-report of } \\
\text { prostate antigen } \\
\text { (PSA). }\end{array}$ & $\begin{array}{l}\text { Initial interview in which } \\
\text { clinical and psychosocial } \\
\text { history is collected, includ- } \\
\text { ing PSA values. Prostate } \\
\text { cancer education, care } \\
\text { coordination assistance } \\
\text { and identification of needs } \\
\text { and available resources } \\
\text { are carried out. Routine } \\
\text { contacts are maintained } \\
\text { where PSA education is } \\
\text { reinforced, symptoms are } \\
\text { evaluated and adherence } \\
\text { to medical controls is } \\
\text { monitored. }\end{array}$ & $\begin{array}{l}\text { There was a growing trend } \\
\text { in the correct report of the } \\
\text { prostatic antigen over time } \\
\text { (18 months). The difference } \\
\text { was significant between } \\
\text { patients receiving } \\
\text { treatment in private versus } \\
\text { public centres. }\end{array}$ \\
\hline
\end{tabular}

\section{Characteristics of the interventions}

The interventions conducted vary in content as well as the mode of delivery. The use of audiovisual materials is featured in $50 \%$ of the studies, where the contents are transmitted mainly through videos created especially for the intervention. These videos may contain a narrative approach [14,15], or mostly illustrative on concepts related to organs affected by cancer according to the tumour site, information regarding treatments and management of adverse effects of treatments [19-21]. In addition to the use of videos, interviews are conducted and/or printed materials are provided with the goal of contextualising the specific clinical situation to each patient $[14,15,19,21]$. Other interventions opt to provide written material in card format [16, 18], whose content is personalised according to the participant's health status, with relevant information according to the objective of the study. Individual and personalised work format is privileged, with only one of the interventions performed in the group workshop format [17]. As for the professionals or roles of those who deliver the interventions, the participants were predominantly nurses [21,22], with minor participation of social workers [17], pharmacists [17] community health workers [18], and figures such as case managers [14, 15] or navigators [16, 18]. 


\section{Effectiveness of interventions}

The effectiveness of the intervention was only reported in those clinical trials that included a control group [14, 15, 17, 21]. For those studies designed with pre- and post-intervention measurements without a control group, the variation in the variable of interest or expected result is reported. For its part, the only qualitative study participants was centred on reporting information of the acceptability and experience of the intervention by the study participants and those that provide the intervention [16]. In general, studies that reported acceptability or conformity of interventions show high satisfaction with the intervention and its content [16, 18, 19]. Furthermore, there is usually a correlation between reported levels of HL and other variables, such as the use of self-care techniques [21], knowledge regarding the illness [19], self-efficacy [17] or adherence to treatments [17].

Clinical trials that include a control group present diverse results. While Rust et al [17] reported an absence of significant differences between both groups after the intervention ( $p=0.83$ ), Jibaja-Weiss et al [15] observed that the intervened patients, contrary to the study's hypothesis, tended to choose complete mastectomies over conservative surgeries despite having a significant increase in the understanding of the disease and its treatment options. In addition, one year follow-up shows no difference between groups regarding knowledge and decisional conflict. On the other hand, in a study by Wilson et al [21] the number of adverse effects to radiation therapy was similar between groups and between patients with high versus low literacy. At the same time, it is observed that the average use of self-care techniques increases over time in all groups, independent of the level of $\mathrm{HL}$, except in the subgroup of patients with low $\mathrm{HL}$ belonging to the control group, in which it decreases.

Prospective cohort studies also present mixed results. The study by Kim et al [19] consists of an audiovisual intervention through compact discs (CD ROM) with the goal to assist in the decision-making process, and had high acceptability, with two-thirds of the patients being able to make a decision by the end of the intervention. However, half of these patients were later prescribed a different treatment decided by themselves during the study. In addition, a correlation between low HL and limited knowledge about prostate cancer was reported. Ulloa et al [18] also reported a high acceptability of the intervention (personalised cards) and an increase in disease knowledge and health status of the participating patients. As for Wang et al [20], the results show an increase in the understanding of prostate cancer terminology, with a significant improvement in patients with low $\mathrm{HL}$ in the understanding of terminology related to sexual function compared to subjects with high HL. Finally, Zavala et al [22] reported an increase in accurate self-reporting of prostate antigen (PSA) during participant follow-up.

\section{Discussion}

The present paper reviews a series of interventions conducted in cancer patients intending to improve their HL. The studies that met these criteria present similarities and differences. Among the similarities, all the studies were conducted in the United States with an important emphasis on including groups considered vulnerable such as Latinos and African Americans. This is consistent with one of the principles that support the relevance of the concept of HL, which is to improve the health outcomes of at-risk groups in order to overcome socio-health inequities [1]. Among the most salient differences is the variability in the methodological design, the content of the interventions and their results.

All studies were designed for subjects with the same cancer diagnosis, either breast or prostate cancer. This implies that the interventions include: 1) specific information about this type of cancer and 2) took certain elements either in their format or content that allude to the diverse gender attitudes present in social discourse, with the goal of achieving closeness and improving acceptability of the intervention. Thus, for example, Jibaja-Weiss et al [14, 15] developed an audiovisual format that emulated a soap opera, while the rewards for patients who reached self-care goals in Wilson's study included male personal care products or tickets for sporting events [21]. The fact that the interventions encompass subjects with the same type of tumour also allowed them to focus on specific aspects of these cancers, such as the selfreporting of PSA [22] or the enrolment in certain clinical trials [14]. The choice of these types of cancer is consistent with both the respective prevalence and the increased survival of the patients [23], as with the trends of prioritisation in cancer research [24]. It is expected that the future research will aim to design interventions targeting subjects with other neoplasms in which HL plays a critical role [25].

The fact that none of the articles reported a definition of HL makes its operationalisation difficult in terms of research and also its conceptual differentiation from other related concepts and variables. A routine question arises as to whether $\mathrm{HL}$ is really an isolable object of study, or if 
it is rather an epiphenomenon of certain situations that occur in health contexts. The difficulty in theoretically isolating the concept and the consensus over its definition has been a constant source of debate between specialists in the field [24]. This difficulty is even greater if one takes into account the multidimensionality of the concept, its relative recent appearance in the scientific field and the variety of instruments that have been developed to date, which emphasize different dimensions of the concept depending on the definition used when designing the tool $[3,7,27,28]$. Consensus on this conceptualisation is of vital importance for the design and reporting of the effectiveness of interventions that promote $\mathrm{HL}$, as has happened in the development of other constructs such as health empowerment [29].

Accordingly, it is observed that the totality of the studies did not seek improvement of $\mathrm{HL}$ as a primary outcome but instead seek some health behaviour or the increase in the knowledge related to the oncological diagnosis. From these studies, it follows that $\mathrm{HL}$ is a variable that correlates with observable behaviours, or measurable outcomes, rather than an outcome itself. This is crucial from a research perspective since it constitutes a key element in the effective evaluation of the interventions performed. In the studies reviewed in this paper, it is observed that the logic of the interventions performed is consistent with the conceptual framework of Echeverri et al [9]. The interventions aimed primarily at improving either the knowledge about the illness or the respective treatments $[14,15,18-20]$, as well as self-knowledge of one's own health status $[18,21,22]$ in order to carry out actions related to decision-making about treatments [14, 15, 19], generate adherence and self-care practices [17, 19], and participation in research [16]. However, the poor conceptualisation of the construct and the use of questioned instruments for the measurement of $\mathrm{HL}$ [30] are problematic since they raise the question of what is understood by $\mathrm{HL}$ and, more importantly, how to modify it effectively.

In effect, it is important to clearly define if the effectiveness of the intervention will be given by the observable changes in the primary outcome or if an intervention that produces results different from those expected while increases elements that are considered part of $\mathrm{HL}$ will also be considered as effective. The study conducted by Jibaja-Weiss et al [15] is illustrative of the dilemma: the patients increased their knowledge of breast cancer as expected, but their attitudes about the treatment of choice changed contrary to the hypothesis, opting more for a different treatment than expected. The study carried out by these authors, therefore, reveals the complexity of HL and its multidimensionality, where behaviours related to treatments associated with greater $\mathrm{HL}$ do not necessarily derive linearly from handling more information about cancer. In this way, it is observed that the behaviours related to HL are determined by multiple components where managing information or having knowledge about the health condition is not synonymous with making decisions based on scientific evidence.

The poor conceptualization of $\mathrm{HL}$ in the articles was the greatest finding, as well as the greatest challenge, of this paper. When grouping the studies and their characteristics, although the included studies met the inclusion criteria of explicitly reporting $\mathrm{HL}$ as a result, in the end, a detailed review of the articles found that they were studies whose focus was primarily other constructs that were affected by the multidimensionality of $\mathrm{HL}$ in their dimensions of knowledge, attitudes, actions and decisions related to cancer behaviours [9]. This makes it impossible to compare the studies, impeding the extraction of conclusions regarding the most effective intervention strategies for vulnerable groups with low HL.

Although no similar reviews were found for the association between $\mathrm{HL}$ and interventions for cancer patients, this literature review is consistent with reviews of $\mathrm{HL}$ and other health conditions [5, 31-35]. In general, there is consensus on the need to improve the methodological quality of the designs, and the reporting of results of the interventions, especially in the long term, in order to find more robust associations between $\mathrm{HL}$ and health outcomes, emphasising the development of interventions for vulnerable groups and their participation in studies. The work of Brainard et al [5], specifically oriented to the methodological quality of clinical trials in HL, highlights the importance of focusing interventions on patient-centred outcomes, in terms of developing high-quality evidence, with meaningful clinical implications. On the other hand, the review conducted by Geboers et al [32] focused on HL and adherence in older adults, underscoring the variability of the interventions and their quality, which makes it impossible to draw conclusions on the most effective type of intervention in this field. Sheridan et al [34] suggested that although certain interventions for people with low HL have been shown to be effective, it is important to continue developing new formats and piloting interventions that combine different elements that can adapt both to the groups they are targeting and to the health condition and its consequences they are seeking to mitigate. Their conclusions are consistent with the results of this review regarding the correlation between educational level and $\mathrm{HL}$ level in study participants. Certainly, those subjects with lower educational level and low $\mathrm{HL}$ are the ones who can benefit mostly from interventions aimed at improving $\mathrm{HL}$, but this requires the use of specific strategies that favour the use of animations, videos or other devices that do not require advanced levels of literacy [9]. However, despite both meth- 
odological and theoretical difficulties, the authors agree that $\mathrm{HL}$ is a promising field of research and development, with a potential impact on patients and health services that merits further study.

One of the strengths of this review is that, to our knowledge, this is the first review carried out on this topic in Spanish (see Spanish version pdf), which accounts for the novelty of the topic and its dissemination in our language. This is a structured review of the literature, so the steps proposed by PRISMA were followed to ensure the quality of the process. Although the articles included were published in journals with a peer review process, and the studies were approved by scientific ethics committees for the protection of the participants, a limitation is that not all the steps established in the PRISMA checklist were performed.

This review could guide health teams in oncology for the development and implementation of interventions at different levels of health services that promote $\mathrm{HL}$, an element that could be considered good clinical practice that entails not only people knowing and understanding more about their disease and treatment options, but also respecting the autonomy and dignity of patients [37]. According to the results, it is feasible to suggest that future research on the subject should be aimed at strengthening the link between theoretical understanding of $\mathrm{HL}$, its measurement and operationalisation and the design of methodologically rigorous studies. In addition, it is appropriate to propose that the acceptability of the intervention should be a reported outcome in a standardised manner in all studies, both by the participating patients and those who deliver the intervention [33]. Finally, it is expected that soon there will be evidence from other countries and cultural realities, as well as the development of interventions and protocols that include other types and stages of cancer (for example, advanced cancer or in the remission/follow-up stage).

\section{Conclusion}

The promotion of $\mathrm{HL}$ in cancer patients is a necessary strategy for delivering quality and patient-centred care. The current state of evidence on the subject accounts for an incipient area of research, is focused mainly on the United States and on breast or prostate cancer. Despite this, the research conducted is heterogeneous in terms of methodological design and the role given to $\mathrm{HL}$ in the intervention. The evidence to date aimed at intervening $\mathrm{HL}$ in patients with cancer focuses on other constructs, leaving $\mathrm{HL}$ as a phenomenon difficult to define conceptually and clinically.

However, it is possible to extract what elements common to the interventions are: 1) the combination of face-to-face interactions with health professionals and the use of multimedia technologies or devices, 2) the emphasis on identifying vulnerable individuals and groups with low $\mathrm{HL}$ and 3 ) the notion that $\mathrm{HL}$ does not operate in isolation but is directly associated with education level, behaviours and factors that influence decisions about one's own health.

Accordingly, the first step for the successful development of HL-related research in oncology is the rigorous and consensual conceptualisation of $\mathrm{HL}$, as well as its delimitation and relationship with other clinical and psychosocial factors that affect the participation and well-being of the person who is being treated for cancer. The progress in research in the area will, in turn, perfect the design of effective interventions, adjust the format and choose appropriate instruments to measure the impact of interventions aimed at improving the impact of $\mathrm{HL}$ in the prevention, diagnosis and treatment of cancer according to the characteristics of each patient group.

\section{Conflicts of interest}

The authors declare that they have no conflicts of interest.

\section{Funding declaration}

This work was supported by the CONICYT National Commission for Scientific and Technological Research National Fund for Scientific and Technological Development (FONDECYT) Chile, FONDECYT Project Initiation in research grant no. 1115221. FONDECYT had no influence 
over the design of the study; in the collection, analysis or interpretation of the data, or in the preparation, review or approval of the manuscript.

\section{Acknowledgments}

The authors would like to thank $\mathrm{G}$ Rojas for her advice as a librarian in the construction of the search strategy. They would also like to thank the anonymous reviewers for their thorough review which significantly improved the quality of the article.

\section{References}

1. World Health Organization Track 2: Health Promotion and Health Behaviour [http://www.who.int/healthpromotion/conferences/7gchp/ track2/en/] Date accessed: 03/07/17

2. Kickbusch I, Pelikan JM, and Apfel F, et al (eds.) (2013) Health literacy: the solid facts. Europe: World Health Organization [http://www. euro.who.int/_data/assets/pdf_file/0008/190655/e96854.pdf.] Date accessed: 21/10/18

3. Edwards M, Wood F, and Davies M, et al (2012) The development of health literacy in patients with a long-term health condition: the health literacy pathway model BMC Public Health 14130 https://doi.org/10.1186/1471-2458-12-130

4. Nutbeam D, McGill B, and Premkumar P (2018) Improving health literacy in community populations: a review of progress Health Promot Int 33 901-911 https://doi.org/10.1093/heapro/dax015

5. Brainard J, Wilsher S, and Salter C, et al (2016) Methodological review: quality of randomized controlled trials in health literacy BMC Health Serv Res 16246 https://doi.org/10.1186/s12913-016-1479-2 PMID: 27402048 PMCID: 4940982

6. Beauchamp A, Buchbinder R, and Dodson S, et al (2015) Distribution of health literacy strengths and weaknesses across sociodemographic groups: a cross-sectional survey using the Health Literacy Questionnaire (HLQ) BMC Public Health 15678 https://doi. org/10.1186/s12889-015-2056-z PMID: 26194350 PMCID: 4508810

7. Bustamante C, Alcayaga C, and Campos S, et al(2008) Literacidad en salud para personas con condiciones de salud crónicas Horizonte 19 97-103

8. Koay K, Schofield P, and Jefford M (2012) Importance of health literacy in oncology Asia-Pac J Clin Oncol 8(1) 14-23 https://doi. org/10.1111/j.1743-7563.2012.01522.x

9. Echeverri M, Anderson D, and Nápoles A, et al (2018) Cancer health literacy and willingness to participate in cancer research and donate bio-specimens Int J Environ Res Public Health 15(10) E2091 https://doi.org/10.3390/ijerph15102091 PMID: 30249985 PMCID: 6211072

10. Ferrari R (2015) Writing narrative style literature reviews Medical Writing 24(4) 230-235 https://doi.org/10.1179/20474806 15Z.000000000329

11. Moher D, Liberati A, and Tetzlaff J, et al (2009) Preferred reporting items for systematic reviews and meta-analyses: the PRISMA statement Ann Intern Med 151 264-269 https://doi.org/10.7326/0003-4819-151-4-200908180-00135 PMID: 19622511

12. Khan KS, Ter Riet G, and Glanville J, et al (2008) Undertaking Systematic Reviews of Research on Effectiveness: CRD's Guidance for Carrying Out or Commissioning Reviews 2nd edn, ed Khalid S Khan (University of York: NHS Centre for Reviews and Dissemination) p 4

13. Davis TC, Williams MV, and Marin E, et al (2002) Health literacy and cancer communication CA Cancer J Clin 52 134-149 https://doi. org/10.3322/canjclin.52.3.134 PMID: 12018928 
14. Jibaja-Weiss ML, Volk RJ, and Friedman LC, et al (2006) Preliminary testing of a just-in-time, user-defined values clarification exercise to aid lower literate women in making informed breast cancer treatment decisions Health Expect 9 218-231 https://doi.org/10.1111/ j.1369-7625.2006.00386.x PMID: 16911136 PMCID: 5060365

15. Jibaja-Weiss ML, Volk RJ, and Granchi TS, et al (2011) Entertainment education for breast cancer surgery decisions: a randomized trial among patients with low health literacy Patient Educ Couns 84 41-48 https://doi.org/10.1016/j.pec.2010.06.009

16. Nickell A, Burke NJ, and Cohen E, et al (2014) Educating low-SES and LEP survivors about breast cancer research: pilot test of the health research engagement intervention J Cancer Educ 29 746-752 https://doi.org/10.1007/s13187-014-0650-x PMID: 24744119 PMCID: 4428555

17. Rust CF, Davis C, and Moore MR (2015) Medication adherence skills training for African-American breast cancer survivors: the effects on health literacy, medication adherence, and self-efficacy Soc Work Health Care 54 33-46 https://doi.org/10.1080/00981389.2014.9 64447 PMID: 25588095

18. Ulloa JG, Hemmelgarn M, and Viveros L, et al (2015) Improving breast cancer survivors' knowledge using a patient-centered intervention Surgery 158(3) 669-675 https://doi.org/10.1016/j.surg.2015.03.056 PMID: 26032819 PMCID: 4820246

19. Kim S, Knight S, and Tomori C, et al (2001) Health literacy and shared decision making for prostate cancer patients with low socioeconomic status Cancer Invest 19 684-691 https://doi.org/10.1081/CNV-100106143 PMID: 11577809

20. Wang D, Jani A, and Sesay M, et al (2014) Video-based educational tool improves patient comprehension of common prostate health terminology Cancer 121 733-740 https://doi.org/10.1002/cncr.29101 PMID: 25393416

21. Wilson F, Mood D, and Nordstrom C, et al (2010) The effect of low literacy on the self-care behaviours of men receiving radiation therapy Nurs Sci Q 23(4) 326-333 https://doi.org/10.1177/0894318410380254 PMID: 20871005

22. Zavala M, Yule A, and Kwan L, et al (2016) Accuracy of PSA Self-reports among low-income men with prostate cancer after a public health nursing intervention Public Health Nurs 33 511-518 https://doi.org/10.1111/phn.12270 PMID: 27157894

23. Jemal A, Siegel R, and Xu J, et al (2010) Cancer Statistics, 2010 CA Cancer J Clin 60 277-300 https://doi.org/10.3322/caac.20073 PMID: 20610543

24. Carter A and Nguyen C (2018) A comparison of cancer burden and research spending reveals discrepancies in the distribution of research funding BMC Public Health 12(1) 526 https://doi.org/10.1186/1471-2458-12-526

25. Megwalu UC (2017) Health literacy in patients with head and neck cancer: an understudied issue JAMA Otolaryngol Head Neck Surg 143(7) 645-646 https://doi.org/10.1001/jamaoto.2017.0242 PMID: 28494059

26. Baker DW (2006) The meaning and the measure of health literacy J Gen Intern Med 21 878-883 https://doi.org/10.1111/j.15251497.2006.00540.x PMID: 16881951 PMCID: 1831571

27. Haun JN, Valerio MA, and McCormack LA, et al (2014) Health literacy measurement: an inventory and descriptive summary of 51 instruments J Health Commun 19(suppl 2) 302-333 https://doi.org/10.1080/10810730.2014.936571 PMID: 25315600

28. Pleasant A, McKinney J, and Rikard RV (2011) Health literacy measurement: a proposed research agenda J Health Commun 16(suppl 3) 11-21 https://doi.org/10.1080/10810730.2011.604392 PMID: 21951240

29. Bravo P, Edwards A, and Barr P, et al (2015) Conceptualising patient empowerment: a mixed methods study BMC Health Serv Res 15 1-14 https://doi.org/10.1186/s12913-015-0907-z

30. Dumenci L, Matsuyama RK, and Kuhn L, et al (2013) On the validity of the shortened rapid estimate of adult literacy in medicine (REALM) scale as a measure of health literacy Commun Methods Meas 7(2) 134-143 https://doi.org/10.1080/19312458.2013.789839 PMID: 23935770 PMCID: $\underline{3736864}$ 
31. Loke YK, Hinz I, and Wang X, et al (2012) Systematic review of consistency between adherence to cardiovascular or diabetes medication and health literacy in older adults Ann Pharmacother 46 863-872 https://doi.org/10.1345/aph.1Q718 PMID: 22669802

32. Geboers B, Brainard JS, and Loke YK, et al (2015) The association of health literacy with adherence in older adults, and its role in interventions: A systematic meta-review BMC Public Health 15903 https://doi.org/10.1186/s12889-015-2251-y PMID: 26377316 PMCID: 4573285

33. Berkman ND, Sheridan SL, and Donahue KE, et al (2011) Health literacy interventions and outcomes: an updated systematic review Evidence Report/Technology Assessment (Rockville, MD: Agency for Healthcare Research and Quality) p 199

34. Sheridan SL, Halpern DJ, and Viera AJ, et al (2011) Interventions for individuals with low health literacy: a systematic review J Health Commun 16(suppl 3) 30-54 https://doi.org/10.1080/10810730.2011.604391 PMID: 21951242

35. Manafo E and Wong S (2012) Health literacy programs for older adults: a systematic literature review Health Educ Res 27947-960 https://doi.org/10.1093/her/cys067 PMID: 22752153

36. Sekhon M, Cartwright M, and Francis J (2017) Acceptability of healthcare interventions: an overview of reviews and development of a theoretical framework BMC Health Serv Res 17(1) 88 https://doi.org/10.1186/s12913-017-2031-8 PMID: 28126032 PMCID: 5267473

37. Sørensen K, Schuh B, and Stapleton G, et al (2013) Exploring the ethical scope of health literacy - a critical literature review Albanian Med J 2 71-83 https://doi.org/10.1186/1471-2458-12-80 